\title{
Sommaire
}

Introduction. $\ldots \ldots \ldots \ldots \ldots \ldots \ldots \ldots \ldots \ldots \ldots \ldots \ldots \ldots \ldots \ldots \ldots \ldots$

\section{Première PARTIE.}

\section{Traditions et transitions:}

des effets de la bile noire au discours du mélancolique $\ldots \ldots \ldots \ldots 13$

I. En deçà de toute littérature: mélancolie grecque et médecine humorale. 15

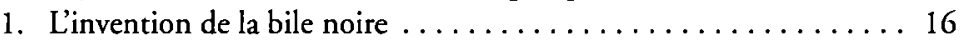

2. Noirceur, résidu, vapeurs: les pouvoirs de la bile noire........ 19

3. Lâme et le corps: des maux de la bile noire à la mélancolie ...... 23

4. Manie, démesure ou désaccord: un mal sans cause. ......... 28

5. Enthousiasme et mélancolie: le Problème $X X X, 1 \ldots \ldots \ldots \ldots 32$

II. Les tempéraments, le mélancolique et l'ordre du monde . . . . . . . 39

1. Des maladies aux tempéraments .................... 40

2. L'exception mélancolique $\ldots \ldots \ldots \ldots \ldots \ldots \ldots \ldots \ldots \ldots$. 45

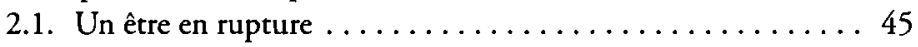

2.2. Marginaux et tyrans mélancoliques............. 48

3. Marsile Ficin et les lettrés mélancoliques .............. 55

III. Des fureurs divines à la misère de l'homme sans dieu:

la mélancolie, le sacré et la condition humaine $\ldots \ldots \ldots \ldots \ldots \ldots 63$

1. La mélancolie entre Dieu et Diable ................. 64

1.1. Furie ou fureur: les délires mélancoliques ...........64 64

1.2. Passion, péché, possession: le corps nié, le corps diabolisé ... 67

1.3. Acedia et tristitia ......................... 70

2. Mélancolie et condition humaine. Pétrarque et le conflit intérieur des désirs. . . . . . . . . . . . . . . . . . . . . 75

IV. Le mélancolique en société: misanthropie et discours satirique . . . . . 89

1. De l'exclusion du misanthrope au discours satirique ......... 89

1.1. Lycanthropes et misanthropes: de Bellérophon à Timon .... 89 
1.2. Démocrite et la genèse du discours mélancolique . . . . . 96

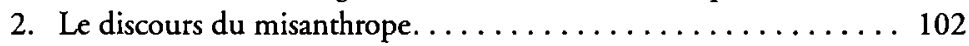

2.1. Le locuteur mélancolique dans son discours . . . . . . 102

2.2. Alceste et le paradoxe du discours misanthropique ....... 105

\section{DeUXIÈME PARTIE}

Du discours sur la mélancolie à l'écriture mélancolique

I. Solitude et sentiment de soi: les Lettres à Malesherbes et l'écriture du sujet mélancolique . . . . . . . . . . . . . . . . . 113

1. Du désaccord à l'harmonie: mélancolie, solitude et conscience de soi. . . . . . . . . . . . . . . . . . . . . . . . . 114

2. Mélancolie de Rousseau: la crise de 1761 et ses interprétations . . 117

2.1. L'interprétation du délire dans le récit des Confessions et dans les lettres de Rousseau. . . . . . . . . . . . . . . . . . . . 119

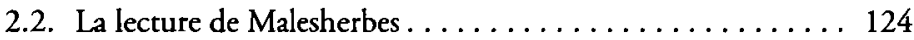

3. Les Lettres à Malesherbes . . . . . . . . . . . . . . . . . . . . . 129

3.1. La réfutation de Malesherbes: aliénation, tempérament et solitude. . . . . . . . . . . . . . . . . . . 130

3.2. Paresse, dégoût, rupture: le retour des valeurs mélancoliques. 134

3.3. "Mais de quoy jouissois-je enfin quand j'étois seul?" . . . . . 138

II. Entre interprétation religieuse et expression poétique:

la mélancolie de René.

1. "Prodigieuse ou "coupable«?

La mélancolie dans Le Génie du christianisme. . . . . . . . . . . 146

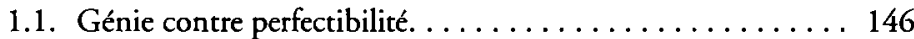

1.2. Le vague des passions . . . . . . . . . . . . . 149

1.3. Le rôle des couvents, la leçon de René et la disparition de la mélancolie ...................... 156

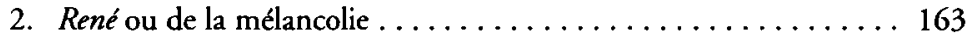

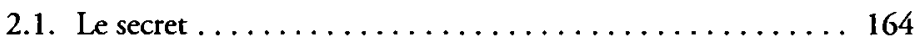

2.2. Un chronotope mélancolique . . . . . . . . . . . 169

2.3. Virgile, René, et la poétique négative de la mélancolie. . . . . 174 


\section{TrOISIÈME PARTIE}

De la mélancolie pathologique à la poétique mélancolique:

E.T.A. Hoffmann et Théophile Gautier

I. La mélancolie dans le discours de la psychiatrie naissante

1. Domaine, compétence et légitimité: le modèle de la maladie et le rôle du corps $\ldots \ldots \ldots \ldots \ldots \ldots \ldots \ldots \ldots \ldots \ldots \ldots$

2. Le monisme des aliénistes: le cerveau, la sympathie, le système nerveux. . . . . . . . . . . . . . . . 191

3. Le modèle unitaire du délire et le rôle de l'imagination . . . . . . . 195

4. La mélancolie et le discours médical sur les passions . . . . . . 202

II. Excentriques heureux et peintres fous: la place de la mélancolie dans l'œuvre narrative d'E.T.A. Hoffmann . . . . . . . . 209

1. Visages de la mélancolie .................. 210

1.1. Les mélancoliques des récits de Hoffmann ......... 213

1.2. La fureur, le corps et la question du sens.

Le rcas، Zacharias Werner . . . . . . . . . . . . . . . . 218

2. De l'excentricité au dualisme: lecture sociale et lecture

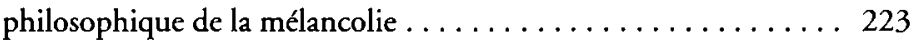

2.1. Ambivalences de la marginalité .............. 223

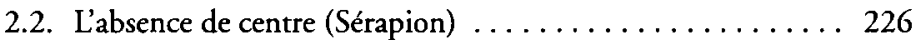

3. L'intérieur et l'extérieur . . . . . . . . . . . . . . . 234

3.1. Mélancolie, amour et réalité (Hermenegilda, Berthold). . . . 234

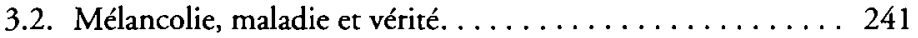

3.3. Mélancolie, impuissance et création . . . . . . . . . 249

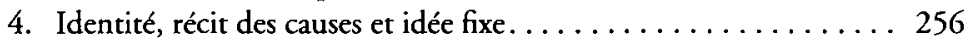

4.1. Lidentité perdue: le secret, le passé et le récit des causes (Theodor, Cardillac) . . . . . . . . . . . . . . . . . . . 257

4.2. L'identité retrouvée: l'idée fixe comme réponse (Sérapion) .. 263

III. Tristesse du roi: la poétique mélancolique de Théophile Gautier . . . 273

1. Les refus de Gautier. . . . . . . . . . . . . . . . . . 274

1.1. La maladie de l'âme et l'impuissance médicale . . . . . . 274

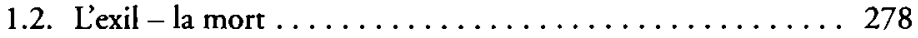

1.3. La pudeur contre les "platitudes prétentieuses«:

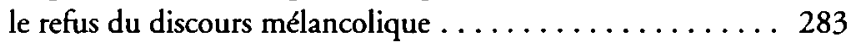

2. Présences du négatif . . . . . . . . . . . . . . . . 289

2.1. Hyperboles et litanies . . . . . . . . . . . . . . . . . . . . . 289

2.2. Statues d'albâtre sur tombeaux . . . . . . . . . . 291

2.3. Paysages de l'âme et demeures mélancoliques . . . . . . . 295

2.4. Portrait du narrateur en mort-vivant. ........... 301 
3. Poétique de l'utopie. ....................... 306

3.1. L'utopie narrative: la rencontre avec la chimère ou le rêve d'une vie sans mélancolie . . . . . . . . . . . . . . 307

3.2. La vie dans l'art: les types ................. 310

3.3. Le monde du parâtre: la théâtralité. .............. 315

3.4. Orient, momies et hiéroglyphes $\ldots \ldots \ldots \ldots \ldots \ldots \ldots . \ldots \ldots$

3.5. Éloge de l'insignifiance: l'utopie de la parole poétique. .... 323

Conclusion.

Bibliographie 